\title{
INCIDENCE OF WORMIAN BONE IN HUMAN SKULLS IN RAJASTHAN
}

William F. Masih, Sumit Gupta, Anita E. Chand, Pratima Jaiswal , P. K. Saraswat

1. Associate Professor. Department of Anatomy, Govt. Medical College, Kota, Rajasthan.

2. Assistant Professor. Department of Anatomy, Govt. Medical College, Kota, Rajasthan.

3. Professor. Department of Microbiology, Govt. Medical College, Kota, Rajasthan.

4. Associate Professor. Department of Anatomy, Govt. Medical College, Kota, Rajasthan.

5. Professor. Department of Forensic Medicine, JLN Medical College, Ajmer, Rajasthan.

\section{CORRESPONDING AUTHOR}

Dr. William F. Masih,

Associate Professor, Dept of Anatomy,

Government Medical College, Kota-324005.

E-mail: dr.williammasih@yahoo.com

Ph: 00919829098863

ABSTRACT: Wormian bones are formations associated with insufficient growth at suture closure and are regarded as epigenetic and hypostatic traits. There exists racial variation in its incidence. AIM: To find the incidence of wormian bone and compare with other study. MATERIAL AND METHOD: This was autopsy study on 150 dead bodies of both sexes of all age groups. RESULT- Incidence of wormian bone in Rajasthan was $4.7 \%$ (4.1\% in males \& $3.6 \%$ in females). This is comparable with study in other part of India \& abroad and it is in accordance with racial variation. CONCLUSION- knowledge of wormian bone is important to neuroanatomist, neurosurgeon, radiologist, anthropologist and morphologist.

KEY WORDS: wormian bone, OS Inca, Interparietal bone, various cranial dystosis.

INTRODUCTION: Wormian bones are accessory bone which occurs within the cranial sutures and fontanelle. Isolated irregular bone frequently occur along various suture line in region of fontanelle and are called wormian bone named after Danish Anatomist" Wormius" They are usually in interparietal portion of occipital bone and remain separate throughout life forming large wormian bone called "OS INCA" 1 .Wormian bone were not differentiated before the age of 20 years in either sex. After the age of 20 years, wormian bone made differential, it is probably because of complete ossification of skull bone with attainment of full size. There may be two separate center of ossification that fails to fuse dividing the parietal bone into upper and lower parts. These bones are separated by sub sagittal suture parallel to the sagittal 1 they usually involve whole thickness or may involve only one table of bone ${ }^{10}$. Wormian bones of the cranial vault are formation associated with insufficient rate of suture closure and regarded as epigenetic or hypostatic trait9. Multiple wormian bones are the prominent feature of various cranial dystosis ${ }^{4}$.

Bhagwat SS et al (1984) 3 found no sex difference in incidence of wormian bones and are genetically determined. Chandershekhran P (1985) ${ }^{4}$ has reported $20 \%$ of wormian bone in skulls of south Indian. Mishra BD (1960) ${ }^{7}$ has also reported case of interparietal bone in his study. Berry AC et al(1974) ${ }^{2}$ reported $4.6 \%$ of Inca bone as non-metrical skeletal variant in North America. Fakharud din S et al $(1967)^{5}$ has reported case of interparietal bone in three pieces in an adult skull and discussed its morphological and developmental importance.

Muthukrishnan S(1987) ${ }^{8}$ reported abnormal occipital bone in Hindu cadaver of 45 years of age. Bhagwat SS et al(1984) ${ }^{3}$ studied 284 skull in Surat (Gujarat) and found no sex difference in 
incidence of wormian bones. They commented that wormian bones are genetically determined. The incidence of true interparietal bone of human skull is found to very rare, this may be in one, two or three pieces. This interparietal bone is believed to be homologous to the post-parietal (dermo-occipatalis) of primitive tetrapod and exist as an unpaired bone in therapiside reptiles ${ }^{6}$. In mammalian skull the interparietal bone is present in carnivores e.g. dog and cat ${ }^{5}$.

The interparietal bone in human skull is represented by that part of squamous occipitals which develop in one membrane. This ossifies in paired center which become continuous with each and with the sub occipital center. Which develop in cartilage, but like most ossification in membrane the number of center may vary 5 .

AIM: To find the incidence of wormian bone.and compare the results with other study in India and abroad.

MATERIAL AND METHOD: Autopsy study was done in department of Anatomy in association with department of Forensic Medicine at J L N Medical college, Ajmer, Rajasthan on 150 human skulls of dead bodies those brought for autopsy. 122 male and 28 female dead bodies of all age group were studied.

Scalp was incised across the vertex from tip of one mastoid process to the other. The scalp tissue was reflected anteriorly up to superciliary arches on forehead and posteriorly up to external protuberance. The vault sutures were completely cleaned by peeling off the temporalis muscle, soft tissues, periosteum and the presence of wormian bone was noted.

OBSERVATION \& DISCUSSION: Incidence of wormian bone was 4.7\% (4.1\% male and $3.6 \%$ female). Out of 150 cases 7 cases showed wormian bone (Table 1). This incidence of wormian bone in present study is slightly higher i.e. $4.7 \%$ than the previous study of Berry AC et al $(1974)^{2}$ who have reported it in $4.6 \%$ of cases. Chandersekharan P $(1985)^{4}$ has reported $20 \%$ incidence of wormian bone in south-India.

The wormian bone were more in male (4.1\%) than in (3.6\%) in present study, whereas most of the previous study, Berry AC et al (1974)2, Chandersekharan P (1985) $)^{4}$, are silent about sex variation in wormian bone. Bhagwat SS et al $(1984)^{3}$ in their study in Gujarat have also found no sex difference in incidence of wormian bone. Murlimanju et al (2011) ${ }^{9}$ reported $73.1 \%$ wormian bone in Indian skull.

The difference in the male/female population needs further study and explanation as no other study has been reported to compare the sex incidence of wormian bone. Other studies were on available skulls whose sex and age were unknown but in our study these were known hence the present documentary evidence needs further study on the population at large.

CONCLUSION: Incidence of wormian bone is $4.1 \%$ in males and $3.6 \%$ in females. The knowledge of wormian bone is clinically important; it may confuse the radiologist in case of head injuries as a multiple fractured bony fragments of skull. It may lead to the problem in posterior approach to cranial cavity. Knowledge of number of wormian bone is important to the anthropologist, radiologist, orthopedic and neurosurgeon.

\section{BIBLIOGRAPHY:}

1. Susan Standring:Gray Anatomy,39th Edi.; page 486 
2. Berry AC (1975).Factor affecting the incidence of Non -metrical skeletal variants,J Ana,120:519-535.

3. Bhagwat SS,Pal GP,Qutal RVR and Patel V91984). A study of sutural bone in Gujrati Crania.J Anat Soc of India, 33(1):3

4. Chandersekharan P(1985).Identification of skull from its suture pattern. Forensic Science International.27:205-214

5. Fakhruddin S and Bhalerao UK (1967), Inerparietal bone in three pieces, a case report, of Ana Soci of Ind, XVI: 146-147.

6. Hymen LH (1957). In Comparative Vertebrate Anatomy, 2nd Ed. University of Chicago Press, Chicago.pg183

7. Mishra BD (1960).Interparietal bone -A case report. J of Anat Soci of Ind., 9:39

8. Muthukrishnan S (1981). Case of abnormal Occipital Bone. J of Anat Soci. Of Ind.29-30

9. Murlimanju BV,Prabhu LV,Ashraf CM,Kumar CG,Rai R and Maheswari C (2011) : J.Morphol.Sci.,vol.28no.3pg.176-179

10. Shapiro R and Janzen HA (1960) .The normal skull-A roentgen study, Paul.B Huber: Inc. Medicals division of Harper and Brothers p.161.

TABLE 1: AGE AND SEX WISE DISTRIBUTION OF WORMIAN BONE (N=150)

\begin{tabular}{|l|c|l|c|c|c|c|}
\hline & \multicolumn{3}{|c|}{ Wormian bone } \\
\hline Age in & \multicolumn{2}{|c|}{ Male } & \multicolumn{2}{c|}{ Female } & \multicolumn{2}{c|}{ Total } \\
\cline { 2 - 7 } & $\begin{array}{l}\text { Yo. of } \\
\text { Cases }\end{array}$ & $\begin{array}{l}\text { Skulls } \\
\text { showing } \\
\text { wormian } \\
\text { bone }\end{array}$ & $\begin{array}{l}\text { No. of } \\
\text { Cases }\end{array}$ & $\begin{array}{l}\text { Skulls } \\
\text { showing } \\
\text { wormian } \\
\text { bone }\end{array}$ & $\begin{array}{l}\text { No. of } \\
\text { Cases }\end{array}$ & $\begin{array}{l}\text { Total Skull } \\
\text { showing } \\
\text { wormian } \\
\text { bone }\end{array}$ \\
\hline $0-30$ year & 51 & - & 18 & & 69 & - \\
\hline $31-40$ & 31 & 2 & 10 & 1 & 41 & 3 \\
\hline $41-50$ & 16 & 2 & 4 & - & 20 & 2 \\
\hline $51-70$ & 16 & 2 & 4 & - & 20 & 2 \\
\hline $71-80$ & 6 & - & 2 & - & 8 & - \\
\hline $81-90$ & 2 & - & 0 & - & 2 & - \\
\hline Total & 122 & 6 & 28 & 1 & 150 & 7 \\
\hline
\end{tabular}

TABLE: 2 Comparison of incidence of wormian bone in Rajasthan with other studies.

\begin{tabular}{|l|l|l|l|}
\hline S. No. & Study & \% of wormian bone & Race \\
\hline 1 & Bhagwat SS et al(1984) $^{3}$ & No sex difference & Gujarat \\
\hline 2 & Chandersekheran P (1985) $^{4}$ & $20 \%$ & South-Indians \\
\hline 3 & Berry et al(1974) $^{2}$ & $4.6 \%$ of Inca bone & North America \\
\hline 4 & Murlimanju et al (2011) $^{9}$ & $73.1 \%$ of wormian bone & India \\
\hline 6. & Present study & $\begin{array}{l}4.7 \% \text { of wormian bone } \\
(4.1 \% \text { in male }) \\
(3.6 \% \text { in female })\end{array}$ & Rajasthan \\
& & & \\
\hline
\end{tabular}




\section{ORIGINAL ARTICLE}

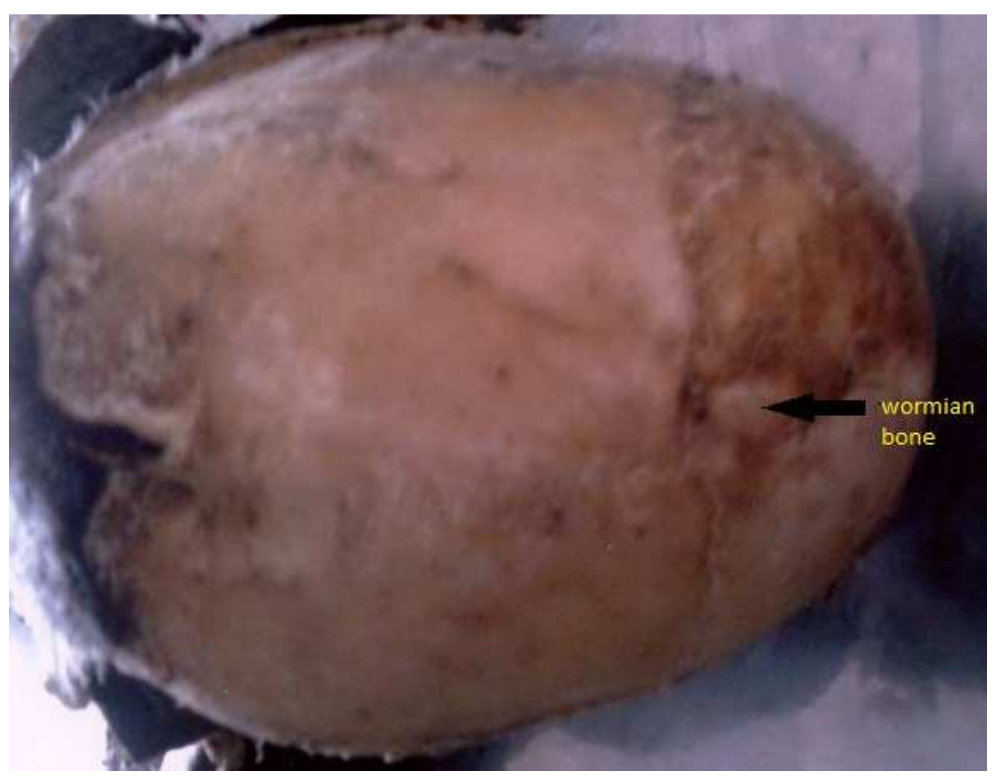

FIGURE -1 Photograph showing wormian bone 